\title{
El GUAJOLOTE NATIVO, ELEMENTO COTIDIANO DEL TRASPATIO EN PLAYA VENTURA, COPALA, GUERRERO, MÉXICO
}

\author{
THE NATIVE TURKEY, AN EVERYDAY BACKYARD ELEMENT IN PLAYA VENTURA, \\ COPALA, GUERRERO, MÉXICO
}

\author{
Alejandro García-Flores*, Elsa Guzmán-Gómez
}

\begin{abstract}
Posgrado en Ciencias Agropecuarias y Desarrollo Rural. Facultad de Ciencias Agropecuaria. Universidad Autónoma del Estado de Morelos. Av. Universidad 1001. Col. Chamilpa. 62209. Cuernavaca, Morelos. (gafa666@hotmail.com)
\end{abstract}

\begin{abstract}
RESUMEN
El objetivo de este trabajo fue conocer la importancia cultural del guajolote nativo mexicano (Meleagris gallopavo Linn.) como sistema de producción campesina en las familias de la comunidad de Playa Ventura, Guerrero. Se aplicaron técnicas etnobiológicas a través de 33 encuestas en unidades familiares, y los datos se analizaron con estadística descriptiva. El sistema de producción es tradicional, con trabajo familiar, con fines de autoconsumo de carne, huevo y otros $(91 \%)$ y venta $(9 \%)$. Se registraron un total de 385 guajolotes, con un promedio de $\mathbf{1 1 . 6}$ por traspatio. Los usos indicados, de acuerdo con las encuestas, fueron: alimento (80 \%), obsequios y regalos (15\%), medicinal (5\%). Es importante mencionar que el $100 \%$ de los informantes utiliza el excremento de esta ave como abono. El manejo preferente es en corral tradicional (89 \%). La alimentación está integrada por maíz quebrado, tortilla remojada, desperdicios de verdura y termitas. Las enfermedades más frecuentes son viruela y diarreas, las cuales son tratadas con remedios caseros. Los conocimientos tradicionales para el manejo de los guajolotes son llevados a cabo y transmitidos en la práctica especialmente por las mujeres de las familias de la comunidad, lo cual garantiza el desarrollo del sistema productivo de guajolote por su significado cultural vigente y su aporte a la alimentación familiar.
\end{abstract}

Palabras clave: alimentación, conocimiento tradicional, manejo, uso, unidad familiar.

\section{INTRODUCCIÓN}

$\mathrm{E}$ n México, dentro del sector pecuario, a la cría de aves domésticas que se desarrolla con prácticas tradicionales se le denomina "avicultura familiar” o "de traspatio" (Sántiz et al., 2012).

* Autor responsable * Author for correspondence. Recibido: mayo, 2013. Aprobado: octubre, 2015.

Publicado como ARTÍ́CULO en ASyD 13: 1-18. 2016.
Abstract

The objective of this study was to identify the cultural importance of the Mexican turkey (Meleagris gallopavo Linn.) serving as a peasant production system amongst families of the community of Playa Ventura, Guerrero. Ethnobiological techniques were applied through 33 surveys carried out in family units, and the data was analyzed with descriptive statistics. The production system is traditional in that it relies on family labor, both for personal consumption of meat, eggs, and others $(91 \%)$, and for sale $(9 \%)$. A total of 385 turkeys were registered with an average of 11.6 per backyard. The uses indicated, according to the surveys, were the following: food $(80 \%)$, gifts $(15 \%)$, medicinal (5\%). It is important to mention that $100 \%$ of the informants utilize this bird's excrement as manure. The preferred mode of management is in a traditional pen (89 \%). Feeding consists of crushed maize, soaked tortilla, vegetable scraps, and termites. The most frequent diseases are turkey pox and diarrhea, which are treated with home remedies. Traditional knowledge regarding how to manage the turkeys is especially employed and transmitted in practice by the women of the families in the community, which guarantees the development of the turkey production system, based on its prevailing cultural significance and contribution to family diet.

Key words: diet, traditional knowledge, management, use, family unit.

\section{INTRODUCTION}

$\mathrm{I}$ n México, within the livestock sector, the breeding of domestic birds developed with traditional practices is referred to as "family aviculture" or "backyard aviculture" (Sántiz, et al., 2012). This activity represents an important source of food and goods for the peasant families that engage 
Esta actividad representa una fuente importante de alimentos y bienes para las familias campesinas que la llevan al cabo, se basa en el trabajo de las familias campesinas, principalmente de la mujer, quien dedica parte de su tiempo a la misma (Allende et al., 2012). En la comunidad de Playa Ventura del municipio de Copala, en la Costa Chica de Guerrero, entre las actividades de traspatio que se desarrollan, está la cría de aves de rancho como gallinas y guajolotes primordialmente para autoconsumo familiar.

La relación entre las culturas indígenas y campesinas mexicanas con el guajolote se remonta a más de siete mil ańos, cuando comenzó el proceso de domesticación (Valadez, 2003). Actualmente existe una serie de relaciones culturales en torno a la figura del guajolote; por ejemplo, se utiliza en ofrendas rituales, trueque, y su plumaje es un componente ornamental (Burcher de Uribe, 1996) y da origen a toponimias en pueblos de origen prehispánico (Díaz del Castillo, 2009). El guajolote (Meleagris gallopavo Linn) históricamente ha contribuido al sustento alimentario y económico de las comunidades rurales y campesinas de México (Medrano, 2000; SAGARPA, 2002).

El conocimiento tradicional del manejo y cría del guajolote en las familias de la comunidad de Playa Ventura, Guerrero, se mantiene vigente en los traspatios, lo cual garantiza la obtención de productos como huevo y carne para el autoconsumo, además de los ingresos económicos cuando se venden los animales o sus productos en el mercado local o en las cabeceras municipales de Copala y Marquelia en la Costa Chica de Guerrero. Actualmente existe interés económico por las familias que crían el guajolote debido a su rendimiento en carne, su bajo costo de producción y la calidad nutritiva por el bajo contenido de grasa de su carne (BSTID, 1991; Castellanos, 2004).

La cría de guajolote como sistema de producción de "ganadería de traspatio" es definida por las mujeres de la comunidad en estudio como la explotación ganadera en pequeña escala, la cual se combina con la cría de gallinas y ganado porcino. Otros autores la denominan "ganadería familiar" (Román, 1989).

Sin embargo, a pesar de la importancia alimentaria, económica y el significado cultural que representa el guajolote para las familias rurales en México, en la actualidad tiende a disminuir o a desaparecer por los cambios de uso del espacio rural y las presiones del crecimiento urbano (Aquino et al., 2003), caso en in it; it is based on the work of the rural families, primarily of women, who dedicate part of their time to this (Allende et al., 2012). In the community of Playa Ventura in the municipality of Copala, in the Costa Chica region of Guerrero, the breeding of farm birds such as hens and turkeys is among the backyard activities that are carried out, mainly for family autoconsumption.

The relationship between Mexican indigenous and peasant cultures and the turkey dates back more than seven thousand years, when the process of domestication began (Valadez, 2003). Today there are a series of cultural relationships around the figure of the turkey; for example, it is used in ritual offerings, in trade, and its plumage is an ornamental component (Burcher de Uribe, 1996), while it also gives rise to local names in towns of Pre-Hispanic origin (Díaz del Castillo, 2009). The turkey (Meleagris gallopavo Linn) has historically contributed to the dietary and economic sustenance of the rural and peasant communities of México (Medrano, 2000; SAGARPA, 2002).

Traditional knowledge regarding the management and breeding of turkey by families of the community of Playa Ventura, Guerrero, is still current in their backyards, which guarantees the procurement of products like eggs and meat for personal consumption, in addition to the economic income from selling the animals or their byproducts in the local market or the townships of Copala and Marquelia, in Guerrero's Costa Chica region. Today, there is economic interest on the part of the families that breed the turkey, due to its yield in meat, its low production cost, and its nutritious quality as a result of the low fat content of the meat (BSTID, 1991; Castellanos, 2004).

Turkey breeding as a "backyard livestock production" system is defined by the women in the community studied as small-scale livestock exploitation that is combined with raising chickens and pigs. Other authors call it "family stockbreeding" (Román, 1989).

However, despite the dietary and economic importance and cultural significance that the turkey represents for rural families in México, today it tends to decrease or disappear due to changes in the use of rural space and the pressures from urban growth (Aquino et al., 2003), a situation in which the community of Playa Ventura finds itself in the face of the outsourcing of their productive activities. 
el que se encuentra la comunidad de Playa Ventura, ante la tercerización de sus actividades productivas. Lo anterior se muestra en los siguientes datos censales, en el año 1990 el sector primario representaba $76.8 \%$ y el terciario $11 \%$; para el 2000 el primario abarcó $65 \%$ y el terciario $28 \%$. Sin embargo, persiste la cría de guajolotes como sistema de ganadería familiar o de traspatio. En este contexto la pregunta de investigación que se planteó fue ¿Cuál es la importancia de los guajolotes nativos para las familias de Playa Ventura del municipio de Copala, Guerrero? La hipótesis argumenta que en los traspatios de la comunidad de Playa Ventura del municipio de Copala, Guerrero, las familias otorgan significado cultural al guajolote nativo por el aporte a la alimentación familiar.

\section{Materiales y Métodos}

\section{Área de estudio}

Playa Ventura se localiza geográficamente en la Sierra Madre del Sur, dentro de la región denominada Costa Chica de Guerrero entre los $16^{\circ} 18^{\prime} \mathrm{N}$ y $98^{\circ} 03^{\prime} \mathrm{O}$ (Figura 1), a una altitud de 10 metros (INEGI, 2010). Cuenta con una población total de 555 habitantes, de los cuales 281 son mujeres y 274 hombres. Existe población indígena, con 24 habitantes amuzgos.

Se presenta un clima cálido subhùmedo con lluvias en verano (Aw1), con una temperatura media anual de 26 a $28{ }^{\circ} \mathrm{C}$. La precipitación media anual oscila entre 1000 y 1500 mm (INEGI, 2009).

La comunidad de estudio pertenece a la región hidrológica Costa Chica-Rio Verde, de la cuenca Río Nexpa (INEGI, 2010). Los cuerpos de agua más importantes para la comunidad son la laguna Cabeza de Charco y el río Copala. Además existen arroyos o apantles como se les conoce localmente, pero estos únicamente abastecen de agua en la época de lluvia a la agricultura y ganadería.

Se practica la agricultura de temporal, de riego y humedad, desarrollando principalmente cultivos de maíz (Zea mays) con asociación de frijol (Phaseolus vulgaris) y calabaza (Cucurbita maxima), jamaica (Hibiscus sabdariffa) y sandía (Citrullus lanatus). La selva baja caducifolia se distribuye principalmente en el Cerro del Coacoyul y se observan relictos en áreas aledañas al pueblo; este tipo de selva se caracteriza por albergar árboles de entre 8 y 12 metros de altura,
This can be seen with the following census data: in 1990 the primary sector represented $76.8 \%$ and the tertiary sector $11 \%$; by the year 2000 , the primary sector encompassed $65 \%$ and the tertiary $28 \%$. Nevertheless, turkey breeding persists as a system of family or backyard livestock production. In this context, the research question set out was: What is the importance of native turkeys for the families of Playa Ventura, in the municipality of Copala, Guerrero? The hypothesis argues that in the backyards of the community of Playa Ventura, in the municipality of Copala, Guerrero, the families assign cultural meaning to the native turkey because of its contribution to family diet.

\section{Materials ANd Methods}

\section{Study area}

Playa Ventura is located geographically in the Sierra Madre del Sur mountain range, within the region called Costa Chica in Guerrero at $16^{\circ} 18^{\prime} \mathrm{N}$ and $98^{\circ} 03^{\prime} \mathrm{W}$ (Figure 1), at an altitude of 10 meters (INEGI, 2010). There is a total population of 555 residents, of which 281 are women and 274 are men. There is an indigenous population of 24 residents of the Amuzgo people.

Playa Ventura has a sub-humid warm climate with summer rains (Aw1), with an annual average temperature of 26 to $28^{\circ} \mathrm{C}$. The average annual precipitation varies between 1000 and $1500 \mathrm{~mm}$ (INEGI, 2009).

The community of studied belongs to the hydrological region of Costa Chica-Río Verde, from the Río Nexpa river basin (INEGI, 2010). The most important bodies of water for the community are the Cabeza de Charco lagoon and the Copala River. There are also streams or apantles, as they are known locally, but these only provide water for agriculture and livestock production during the rainy season.

Rainfed agriculture is practiced, with irrigation and humidity, developing primarily maize crops (Zea mays) with association to bean (Phaseolus vulgaris) and squash (Cucurbita maxima), hibiscus (Hibiscus sabdariffa), and watermelon (Citrullus lanatus). The low deciduous forest is distributed mainly on the Cerro Coacoyul mountain and some residual forest can be observed in areas surrounding the community; this type of forest characteristically 


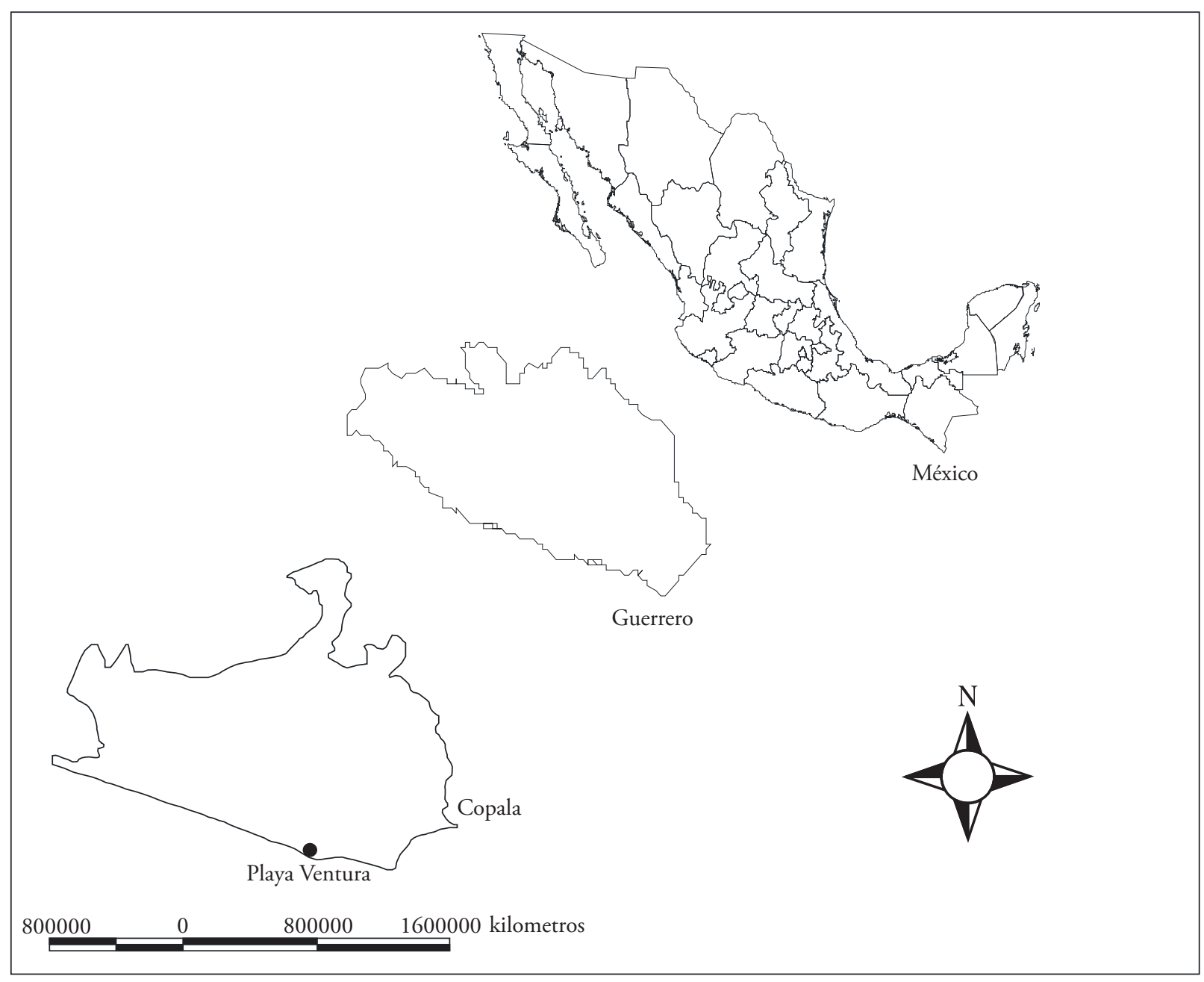

Fuente: INEGI, 2010.

Figura 1. Ubicación de la comunidad de Playa Ventura, Copala Guerrero, México. Figure 1. Location of the community of Playa Ventura, Copala, Guerrero, México.

que durante la temporada de secas la mayor parte de las copas pierden sus hojas. El manglar es otro tipo de vegetación que se localiza al oriente de la comunidad conformado por árboles de mangle Rhozophora mangle, el cual aporta leña que utilizan las familias como combustible (García, 2013).

\section{Metodología}

Se realizaron visitas a la comunidad para informar a los pobladores sobre el propósito del trabajo y contar con su participación en el levantamiento de las encuestas. Posteriormente se realizaron recorridos con guías locales a las casas de las familias con avicultura de traspatio con presencia de guajolotes, bajo harbors trees between 8 and 12 meters tall, which during the dry season lose the majority of their leaves. The mangrove is another type of vegetation located to the east of the community, made up of Rhozophora mangle mangrove trees, which provide firewood that the families use as fuel (García, 2013).

\section{Methodology}

Visits were carried out to the community to inform the residents about the purpose of the project and to gain their participation in answering the surveys. Subsequently, visits were made with local guides to the homes of the families with backyard aviculture with the presence of turkeys, under the 
los criterios que proponen Aquino et al. (2003), que consiste en la identificación de unidades productivas familiares con crianza de guajolote nativo y que estén dispuestas a colaborar con la investigación. Además, con base en la propuesta de la FAO (2001), se describió la morfología (color del plumaje) del guajolote Meleagris gallopavo Linn. Para recopilar la información sobre el conocimiento tradicional se aplicaron técnicas etnobiológicas tales como entrevistas abiertas y encuestas semiestructuradas; se encuestó a las mujeres de los traspatios elegidos (Barrera, 1983; Martin, 1997).

Se realizaron entrevistas semiestructuradas con base en un cuestionario previo en el que se obtuvo el nombre común, interés en la crianza, formas de manejo y uso, enfermedades, tratamientos, comercialización y destino de la producción. A las primeras mujeres entrevistadas se les solicitó que guiaran las visitas a otras casas, lo cual aceptaron. El lenguaje utilizado durante la entrevista fue coloquial, lo que generó confianza con las personas encuestadas. Algunas entrevistas se grabaron con el consentimiento del informante (Sturtevant, 1964; Bellamy, 1996; Costa-Neto, 2000). Complementariamente el trabajo de campo se apoyó en las técnicas de observación participante y diálogo dirigido (Rodríguez et al., 2012). La información recopilada se analizó con estadística descriptiva.

Se muestrearon 33 traspatios donde se aplicaron entrevistas a 31 amas de casa y a dos jefes de familia, tomando como base el cuestionario semiestructurado.

\section{Resultados y Discusión}

\section{La estrategia familiar productiva}

El estudio de los grupos campesinos y sus sistemas de producción tiene vigencia actualmente para comprender la complejidad de las relaciones y su persistencia en la sociedad. La importancia radica en la consideración de los conocimientos locales, en el papel que cumplen en la producción de alimentos, en el uso de los recursos naturales, y en las nuevas funciones que se han asignado a los paisajes rurales en la recreación humana y como estilo de vida alternativo (Delgado, 2008).

La estrategia productiva se construye teniendo como base a la unidad doméstica o familiar, con el objetivo del mantenimiento y reproducción social de sus integrantes. Las actividades que conjuntan a la estrategia tienen diferentes objetivos, tanto de uso criteria proposed by Aquino et al. (2003), consisting in the identification of productive family units which breed native turkeys and willing to collaborate with the research. In addition, based on the proposal by FAO (2001), the morphology (plumage color) of the Meleagris gallopavo Linn was described. To collect information about traditional knowledge, ethnobiological techniques were applied such as open interviews and semi-structured surveys; the women from the chosen backyards were surveyed (Barrera, 1983; Martin, 1997).

Semi-structured interviews were carried out based on a previous questionnaire in which data was obtained including the common name, interest in breeding, ways of management and use, diseases, treatments, commercialization, and destination of the production. The first women interviewed were asked to guide the visits to other houses, which they accepted. The language used during the interview was colloquial, which generated confidence in the people interviewed. Some interviews were recorded with the consent of the informant (Sturtevant, 1964; Bellamy, 1996; Costa-Neto, 2000). Complimentarily, fieldwork relied on participant observation and directed dialogue techniques (Rodríguez et al., 2012). The information gathered was analyzed with descriptive statistics.

Thirty-three backyards were sampled, where 31 interviews were applied to housewives and to two heads of family, using as a basis the semi-structured questionnaire.

\section{Results AND Discussion}

\section{The family production strategy}

The study of peasant groups and their production systems has current validity to comprehend the complexity of relationships and their persistence in society. The importance lies in the consideration of local knowledge, in the role that it plays in food production, in the use of natural resources, and in the new functions that have been assigned to rural landscapes for human recreation and alternative lifestyles (Delgado, 2008).

The productive strategy is constructed by having the domestic or family unit as a basis, with the objective of the maintenance and social reproduction of its members. The activities that comprise the 
como de destino al mercado, para responder a las diferentes necesidades de la familia. La familia se organiza en el desarrollo de las tareas que se proponen de acuerdo al sexo y a la edad en una estructura jerárquica (Martínez y Domínguez, 1992; Cragnolino, 2002; Lanza y Rojas, 2010). En la comunidad de Playa Ventura, las unidades de producción conjuntan una estrategia conformada por la producción del traspatio, la agricultura (milpa y cultivos asociados), ganadería mayor y menor, la pesca ribereña, la cacería de subsistencia, la recolección de plantas (frutos, medicinales, leña) y servicios de turismo y ecoturismo. A través de esta estrategia la familia usa, maneja y reproduce los recursos naturales, además de transmitir en los procesos cotidianos el conocimiento ancestral heredado de padres a hijos, así como herramientas tradicionales que les permiten realizar el manejo integrado de sus recursos (suelo, agua, plantas, animales y recursos marinos) presentes en su territorio.

\section{Los traspatios como subsistemas integrales}

Dentro de la estrategia familiar de la comunidad de Playa Ventura, interesa resaltar el papel del traspatio como ámbito de reproducción del guajolote, objeto de este estudio.

El traspatio (TP) (Jerez, 1994; Steinberg, 1998), huerto familiar (HF), solar (Estrada et al., 1998) o también llamado huerto casero (Lok, 1998), es el espacio distribuidos en las áreas rurales de México donde se aprovecha el área física circundante a la vivienda donde habita la familia campesina (Lerner et al., 2009).

En el establecimiento, cuidado y manejo de los traspatios participan activamente los integrantes de la familia; de esta manera se obtienen frutas, semillas, legumbres, flores, tubérculos y tallos (Juan y Madrigal, 2005). El trabajo del traspatio en la comunidad de Playa Ventura se divide entre los miembros de la familia, donde la mujer, además de otras tareas asignadas a su género como la limpieza de la casa, la preparación de los alimentos y el cuidado de los hijos, es responsable de la organización y funcionamiento general, lo que se traduce en un ámbito de confianza y decisión, tanto en la realización de tareas productivas, venta de productos como huevo y animales, o intercambio de animales o plantas con otras mujeres.

En cuanto a los componentes y producción del traspatio, estos resultan altamente productivos, considerando que en su limitada superficie $\left(200 \mathrm{~m}^{2}\right.$ en strategy have different objectives, both in use and in market destination, to respond to different family needs. The family organizes itself by developing the tasks that are proposed according to sex and age in a hierarchical structure (Martínez and Domínguez, 1992; Cragnolino, 2002; Lanza and Rojas, 2010). In the Playa Ventura community, the production units comprise a strategy made up of backyard production, agriculture (maize and associated crops), major and minor livestock, riverside fishing, subsistence hunting, plant recollection (fruits, medicinal plants, firewood), and tourism and ecotourism services. Through this strategy, the family uses, manages, and reproduces natural resources, in addition to transmitting in everyday processes their ancestral knowledge inherited from parents to children, while traditional tools allow them to carry out the integrated management of resources (soil, water, plants, animals, and marine resources) present in their territory.

\section{Backyards as integral subsystems}

Within the family strategy of the community of Playa Ventura, it is worth highlighting the role that the backyard plays as an environment for turkey reproduction, the object of this study.

The backyard (BY) (Jerez, 1994; Steinberg, 1998), family garden (FG), solar (Estrada et al., 1998) or also called home vegetable garden (Lok, 1998) is the space distributed in rural areas of México where the physical area surrounding the property where the peasant family resides is exploited (Lerner et al., 2009).

Members of the family actively participate in the establishment, care, and management of these backyards; in this way they obtain fruit, seeds, legumes, flowers, tubers, and stems (Juan and Madrigal, 2005). Backyard work in the Playa Ventura community is divided between members of the family, where the woman, apart from other tasks assigned to her gender such as cleaning the house, preparing food, and caring for children, is responsible for its organization and general operation, which is relayed in a sphere of confidence and decision-making, both in performing productive tasks, selling products like eggs and animals, or trading plants or animals with other women.

With regard to the components and production in the backyard, these turn out to be highly productive, considering that in its limited surface area $\left(200 \mathrm{~m}^{2}\right.$ on 
promedio) hace constantes y diversas aportaciones a la unidad doméstica; involucra un trabajo basado en una vasta biodiversidad, turnando durante el ciclo productivo diversos cultivos tradicionales. En el traspatio se crían animales domésticos y para el manejo general de ese espacio se aprovecha el conocimiento tradicional y recursos disponibles en la unidad de producción. Las contribuciones que el traspatio rinde a la economía doméstica son múltiples y considerables, y éstas se presentan en versiones de ahorro o bien como pequeños ingresos monetarios, así como el aporte básico de productos para la dieta tradicional de la familia, y de vez en cuando se intercambian con vecinos y familiares los productos cosechados, o incluso se comercializan en las plazas locales (Rodríguez, 2006; Rodríguez et al., 2010).

En la jornada de trabajo, la mujer combina las tareas de atención al esposo e hijos, del cuidado de la casa y del traspatio. Saca del gallinero las aves para que tomen baños de sol y busquen insectos o pasto para comer, libera a los "cochis", cabras del corral y los acompaña a pastorear unas horas al monte; mientras las cabras se alimentan, ella aprovecha para recolectar plantas medicinales, frutos y leña. Por la tarde, limpia sus plantas, remueve la tierra, limpia los albergues de sus animales (gallinas, guajolotes, cerdos, cabras) y cosecha algunos productos. Las mujeres comparten productos como cocos, plantas medicinales, huevos, pollos, "pípilos" o fruta de temporada. Las tareas también incluyen la selección de alimentos de los animales, curación con remedios caseros, dirigen la construcción de corrales y venta de animales.

Los productos de los traspatios de la comunidad aportan bienes de consumo a la seguridad alimentaria y los ingresos familiares, favorecen las oportunidades para mejorar la calidad de vida de la familia. Así las mujeres, en este espacio realizan actividades con base en sus gustos y preferencias en beneficio de la familia. Saben que el traspatio es su alternativa de apoyo para los tiempos de crisis económica y alimentaria. Los conocimientos generados son transmitidos de una generación a otra, y la enseñanza y aprendizaje son continuos.

\section{La cría de guajolotes como subsistema del traspatio}

Las mujeres y varones de la comunidad nombran al guajolote como "pípilo" o "totol". En otras comunidades o regiones de México se le conoce como "cocono", average), it makes constant and diverse contributions to the domestic unit; it involves work based on vast biodiversity, alternating during the productive cycle various traditional crops. In the backyard, domestic animals are raised and traditional knowledge and available resources are taken advantage of for the general management of this space in the production unit. The contributions that the backyard yields to domestic economy are multiple and considerable, and these are present as savings or small monetary incomes, in addition to the basic contribution of products for the traditional family diet, and from time to time, the harvested products are traded with neighbors and family members, or they are even commercialized in local markets (Rodríguez, 2006; Rodríguez et al., 2010).

In the work day, the woman combines tasks including attending to her husband and children, maintaining the house, and maintaining the backyard. She lets the birds out of the henhouse so they may take sun baths and search for insects or grass to eat, she lets the cochis and goats out of their pen, and takes them to graze for a few hours on the underbrush; while the goats feed, she takes advantage of this time to gather medicinal plants, fruits, and firewood. In the afternoon, she cleans the plants, removes soil, cleans the animal pens (chickens, turkeys, pigs, goats) and harvests some produce. The women share products such as coconuts, medicinal plants, eggs, chickens, pipilos or turkeys, or seasonal fruit. Their tasks also include selecting food for the animals, healing with home remedies, directing the construction of pens, and selling animals.

The community's backyard products contribute consumer goods for foo security and family income, favoring opportunities to improve the family's quality of life. In this way, women perform activities in this space based on their tastes and preferences in benefit of the family. They know that the backyard is their alternative for support during times of economic and food crisis. The knowledge generated is transmitted from one generation to another, and education and learning are continuous.

\section{Breeding turkeys as a subsystem of the backyard}

The women and men of the community call the turkey pipilo or totol. In other communities or regions 
"huilo", "kunito" y "picho" entre otros toponimios (Llamas, 2005).

La avicultura en la comunidad en estudio es una actividad popular que se relaciona con la cría de animales domésticos entre los cuales destacan guajolotes, gallinas, "cochis" (cerdos), cabras y en menor proporción vacas. Noventa y cuatro por ciento de las mujeres entrevistadas se encargan de la cría al guajolote y son ellas quienes dirigen el trabajo. Estos resultados coinciden con otros estudios realizados con productores de Xoxocotla, Morelos (García et al., 2012), Dzununcan, Yucatán (Rodríguez et al., 1996), Texán y Tzacala en Mérida, Yucatán (Rejón et al., 1996). Seis por ciento de los entrevistados correspondió a jefes de familia, en virtud de que la figura de ama de casa no está presente y es el varón (padre) quien organiza las tareas de manejo del guajolote y traspatio en conjunto con hijas y nietos.

El sistema de producción de guajolote criollo (Meleagris gallopavo) identificado con base en datos de la FAO (2002) en la comunidad es de tipo tradicional, desarrollado por las unidades familiares en los traspatios de las casas habitación, en la que sus integrantes (jefe de familia, mujer, hijos, nietos y nueras) aportan el trabajo. Lo anterior coincide con Soler (2010), que plantea que los sistemas pecuarios de producción campesina, también llamados producciones de traspatio, son actividades desarrolladas por la unidad doméstica familiar, que consiste en la crianza de aves de diversas especies en los patios, de las casas de las comunidades rurales, en las que se utilizan pocos insumos, la mano de obra para el manejo de los animales es aportada por los miembros de la familia y los productos que se obtienen se destinan principalmente al autoconsumo.

Se registraron un total de 385 guajolotes criados por 31 mujeres y 2 varones (jefes de familia) de la comunidad. Del total de animales registrados $39.5 \%(n=152)$ fueron hembras, adultas llamadas localmente pípilas, $22.4 \%(\mathrm{n}=86)$ machos adultos y $38.1 \%(\mathrm{n}=147)$ "pipilitos" sin diferenciar su sexo. El promedio de guajolotes por unidad familiar o traspatio fue de 11.6, con una varianza de 6.5, alcanzando un máximo de 25 guajolotes para un traspatio y un mínimo de tres para cuatro traspatios.

El promedio de guajolotes machos por traspatio fue de 2.60 , con una varianza de 1.49 , con un máximo de 59 guajolotes y un mínimo de 1 por traspatio. El promedio de hembras por traspatio fue de 4.60, of México, turkeys are known as cocono, huilo, kunito, and picho, among other local names (Llamas, 2005).

Aviculture in the community studied is a popular activity that is related to the breeding of domestic animals, among which turkeys, chickens, cochis (pigs), goats, and to a lesser degree cows, are prominent. Ninety-four percent of the interviewed women are in charge of breeding the turkeys and it is they who direct the work. These results coincide with other studies done with producers of Xoxocotla, Morelos (García et al., 2012), Dzununcan, Yucatán (Rodríguez et al., 1996), and Texán and Tzacala in Mérida, Yucatán (Rejón et al., 1996). Six percent of those interviewed corresponded to heads of households, since the housewife figure is not present and it is the male (father) who organizes tasks involving management of the turkey and backyard, with help from daughters and grandchildren.

The Creole turkey (Meleagris gallopavo) production system in the community, identified based on data from FAO (2002), is of a traditional type, developed by the family units in the backyards of their homes, and for which the family members (head of household, woman, children, grandchildren, and daughters- in-law) contribute with labor. This coincides with Soler (2010), who suggests that the peasant livestock production systems, also known as backyard production, are activities developed by the domestic family unit, which consists in the breeding of various species of birds in the household yards of rural communities, where few supplies are utilized, the workforce for animal breeding is provided by the family members, and the products obtained are destined primarily to personal consumption.

A total of 385 turkeys were registered, bred by 31 women and 2 men (heads of households) from the community. Of the total animals registered, $39.5 \%$ $(\mathrm{n}=152)$ were adult females, locally called pipilas, $22.4 \%(\mathrm{n}=86)$ were adult males, and $38.1 \%$ $(\mathrm{n}=147)$ were pipilitos, without differentiating their sex. The average number of turkeys per family unit or backyard was 11.6 , with a variance of 6.5 , reaching a maximum of 25 turkeys for one backyard and a minimum of three for four backyards.

The average of male turkeys per backyard was 2.60 , with a variance of 1.49 , a maximum of 5.9 turkeys and a minimum of 1 per backyard. The average of females per backyard was 4.60, with a variance of 5.24, a maximum of 9 and a minimum 
con una varianza de 5.24, con un máximo de 9 y un mínimo de 2 individuos por traspatio. El promedio de "pipilitos" fue de 4.45, con varianza de 43.22, con un máximo de 12 y un mínimo de cero registrados por traspatio.

La magnitud de la varianza muestra la gran dispersión que existe entre los traspatios en el número de guajolotes con respecto al promedio. En $65 \%$ de los traspatios tienen menos individuos (tanto machos, hembras como pípilos que el promedio, con un mínimo de 1 para los machos, dos para las hembras y cero pípilos. Relacionando este dato con que en 14 traspatios no se contaban con crías en el momento de las entrevistas, destaca que existen dificultades en la reproducción o cría por propensión a enfermedades. De esta manera mejor se opta por evitar la postura en época de lluvias, manteniendo la presencia de al menos un macho y dos hembras, lo que marca un interés en seguirlo reproduciendo. Cuando en la unidad de producción se quedan sin guajolotes, las mujeres piden prestados, compran o intercambian por otros productos parejas de guajolotes para iniciar nuevamente la cría.

Los 15 traspatios que cuentan con más individuos que el promedio representan menos de la mitad del total. Es decir, hay más traspatios $(65 \%)$ con menos individuos, lo que indica la falta de interés o dificultad para incrementar o sostener la productividad de los animales.

La preferencia por tener más guajolotas o "pípilas" adultas $(n=152)$ se debe, a mención principalmente de las mujeres entrevistadas, por el aporte de huevos y carne que son utilizados como alimento de la familia. Además el huevo es utilizado en medicina tradicional.

Se registraron dos colores de plumaje de los guajolotes (fenotipo) con base en la metodología propuesta por la FAO (2001): $55 \%$ guajolotes con plumaje gris $(n=212)$, observado principalmente en hembras adultas y $45 \%$ de color negro en machos adultos $(n=173)$, los mismos colores son reportados por Allende et al. (2012) para los guajolotes de la localidad de Zompantle, municipio de Asunción Cacalotepec, Oaxaca. Sobre los colores de los guajolotes García et al. (2012), reportan además de estos colores, al blanco y café para la comunidad de Xoxocotla en Morelos. Al cuestionar si existía alguna preferencia por el color la señora Reina Pérez, menciona "preferimos el color negro y gris porque su carne es más sabrosa, además de que las pípilas son buenas of 2 individuals per backyard. The average of pipilitos was 4.45 , with a variance of 43.22 , a maximum of 12 and a minimum of zero registered per backyard.

The magnitude of variance shows the great dispersion there is between backyards in the number of turkeys with respect to the average. Sixty-five percent of backyards have fewer individuals (males and females, as well as pipilos), with a minimum of one for the males, two for the females, and zero for the pipilos. Relating this data with the fact that in 14 backyards there were no offspring at the moment of the interviews, it stands out that there are difficulties in reproduction or breeding because of propensity for disease. Therefore, a better option is to avoid egg-laying during the rainy season, maintaining the presence of at least one male and two females, something that signals an interest in continuing to breed the bird. When a production unit is left without any turkeys, the women ask to borrow, they buy or they trade other products for a pair of turkeys to once again begin the breeding process.

The 15 backyards that have more individuals than the average represent less than half of the total. That is, there are more backyards (65\%) with fewer individuals, indicating a lack of interest or difficulty in increasing or sustaining the animals' productivity.

Preference for having more adult female turkeys or pipilas $(\mathrm{n}=152)$ is due, according to the women interviewed, to the provision of eggs and meat that are utilized for the family diet. Also, the eggs are used in traditional medicine.

Two plumage colors (phenotypes) were registered in the turkeys, based on the methodology laid out by FAO (2001): $55 \%$ of turkeys had grey plumage $(\mathrm{n}=212)$, observed mainly in adult females, and $45 \%$ were black, observed in adult males $(n=173)$; the same colors are reported by Allende et al. (2012) for the turkeys in the locality of Zompantle, municipality of Asunción Cacalotepec, Oaxaca. Regarding the colors of turkeys, García et al. (2012) also report white and brown for the Xoxocotla community in Morelos. When asked if there was some color preference, Reina Pérez stated: "we prefer the colors black and grey because the meat is tastier, and also because those pipilas are good egg-layers; in Copala I have seen other colors like white and brown, but those are improved; we are used to the black and grey". It seems that these types of turkeys 
ponedoras, en Copala he visto otros colores como el blanco y café pero esos ya son mejoradas, nosotros ya estamos acostumbradas al negro y gris". Parecería que este tipo de guajolotes son los que mejor se adaptan a las condiciones de manejo y clima la comunidad.

Aquino et al. (2003), Camacho et al. (2008) y García et al. (2012) recomiendan considerar el color del plumaje para estudios posteriores como un elemento útil para diseñar programas de genética, porque el mosaico de color en las plumas indica el grado de cruzamiento que tienen los guajolotes.

\section{Organización del trabajo y manejo del subsistema de guajolotes}

Se resalta el trabajo de la mujer, ya que es clave en el desarrollo y preservación de esta actividad en los traspatios. Al respecto Gutiérrez et al. (2012) también mencionan que la atención de los animales de traspatio es una actividad desempeñada principalmente por las mujeres; las que destinan a las labores con el guajolote de 30 minutos a 2 horas en función de la actividad. Similares resultados reportan Hernández y Jaimes (2003), Vieyra et al. (2004), Losada et al. (2006), que además resaltan la importancia de la mujer en el mantenimiento de los traspatios. Así, $74 \%$ de las mujeres entrevistadas organizan los alimentos que se les darán a los animales, mientras que $15 \%$ de hombres apoyan con el transporte de alimento proveniente de la parcela. El manejo de enfermedades y la preparación de los remedios caseros para curarlas, así como la venta de los animales o sus productos, tales como el huevo, son actividades propias de la ama de casa. La limpieza de los corrales se divide entre las amas de casa (80 \%), hijos $(10 \%)$ y nueras $(10 \%)$. El jefe de familia construye los gallineros ( $80 \%)$ o encierros para los guajolotes y las aves del traspatio; sin embargo, $20 \%$ de las mujeres apoyan en la construcción, seleccionan el espacio y los materiales a utilizar. Los hijos y nueras también participan en las diferentes labores pero en menor proporción, por ejemplo, apoyan en dar de comer o poner agua a los guajolotes, a colectar los huevos. Además las mujeres $(100 \%)$ son quienes supervisan y ponen en cuarentena a los animales enfermos (Figura 2). Cabe mencionar que las mujeres en todo momento supervisan las labores que realizan cada uno de los miembros de las familias.

Respecto al manejo, se considera del tipo tradicional, ya que no existen elementos tecnológicos are the ones better adapted to the management and climate conditions of the community.

Aquino et al. (2003), Camacho et al. (2008) and García et al. (2012) recommend considering the plumage color for subsequent studies, as a useful element in designing genetics programs, because the color mosaic in the feathers indicates the degree of crossbreeding that the turkeys have.

\section{Work organization and management of the turkey subsystem}

The work of the woman is emphasized, since it is key to the development and preservation of this backyard activity. In that regard, Gutiérrez et al. (2012) also mention that tending to animals in the backyard is an activity executed principally by women; they allot 30 minutes to 2 hours of work with the turkeys for this activity. Similar results have been reported by Hernández and Jaimes (2003), Vieyra et al. (2004), and Losada et al. (2006), who in addition underline the importance of women in maintaining the backyards. Thus, $74 \%$ of the women interviewed organize the food that will be given to the animals, while $15 \%$ of the men help with the transportation of food from the plot. Managing diseases and preparing home remedies to cure them, as well as the sale of animals or their products like eggs, are activities belonging to the housewife. Cleaning the pens is divided between the housewives $(80 \%)$, children (10\%) and daughtersin-law $(10 \%)$. The head of household builds the henhouses $(80 \%)$ or enclosures for the turkeys and other backyard birds; however, $20 \%$ of the women assist in building, selecting the allotted space and materials to be utilized. The children and daughtersin-law also participate in different tasks but in to a lesser degree; for example, they assist in feeding or providing water for the turkeys, and collecting eggs. Moreover, the women $(100 \%)$ are the ones who supervise and quarantine the sick animals (Figure 2 ). It is worth mentioning that the women at all times supervise the work carried out by every other member of the families.

Concerning management, it is considered of a traditional type, since there are no technological elements oriented towards feeding the animals, handling disease, genetics, reproduction, and commercialization. The traditional pen $(89 \%)$ is the 


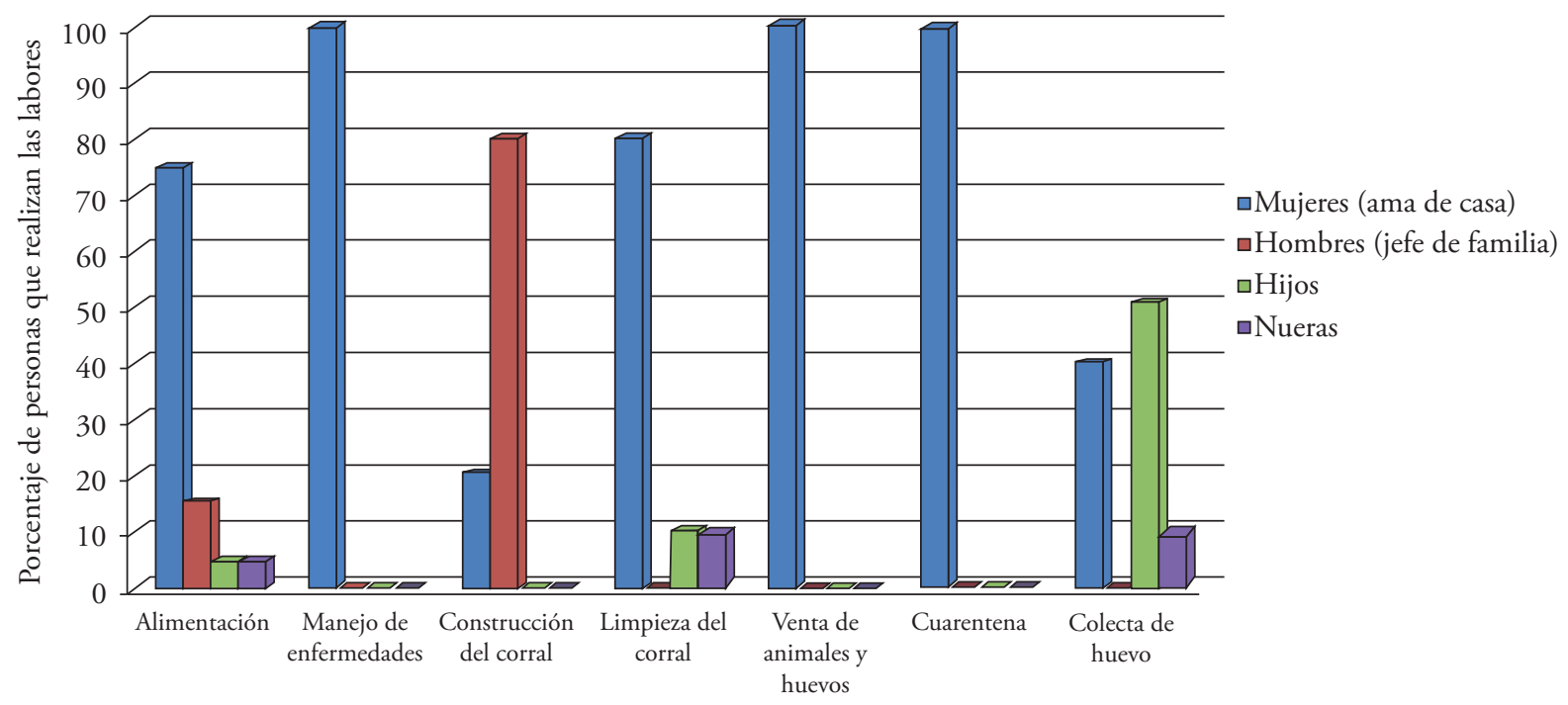

Labores del traspatio relacionadas con la cría de guajolote

Figura 2. Distribución de las labores por integrante de las unidades familiares que crían guajolote en Playa Ventura, Copala, Guerrero.

Figure 2. Distribution of tasks per member of the family units that breed wild turkey in Playa Ventura, Copala, Guerrero.

orientados a la alimentación de los animales, manejo de enfermedades, genética, reproducción y comercialización. El corral tradicional (89 \%) es la forma preferida por las mujeres para mantener encerrados a los guajolotes, mismos que son construidos por el jefe de familia con hoja de palma y palos de diferentes plantas del monte (quebrache, palma, zopilote, parota y huizache). Este consta de un área aproximada de $15 \mathrm{~m}^{2}$ con una puerta de acceso que permite el paso a los miembros de la unidad familiar para llevar a cabo diferentes labores. Dentro del corral las mujeres habilitan espacios construidos con materiales de la región (bejucos) para que los animales descansen y "Chitas" para que las "pípilas" depositen sus huevos y los empollen. Otros materiales complementarios al corral son la tela de gallinero (11\%), para el techo se utilizan enramadas construidas con ramas frescas y secas de palma. Es común también observar que anden sueltos los animales en el traspatio aledaño a la casa donde se alimentan de hierbas e insectos. Cuando cae la tarde las mujeres localizan y arrean a los guajolotes, gallinas, y puercos, junto con sus crías a la casa para su resguardo en el corral. Para evitar la confusión de animales en cuanto a la propiedad se les amarra un hilo de color en la pata; lo mismo reporta Bautista (2006) para la región Mixe en Oaxaca.

La alimentación de los guajolotes es tradicional: está integrada por maíz quebrado, tortilla remojada, method for turkey enclosure preferred by the women, and these are built by the heads of the household with palm leaves and branches from different plants from the underbrush (quebrache, palm, zopilote or Mexican Mahagony, parota, and huizache). The pen covers an area of approximately $15 \mathrm{~m}^{2}$ with an access door that permits passage of members from the family unit to carry out various tasks. Within the pen, women set up spaces constructed with materials from the region (reeds or vines), so that the animals can rest, and chitas, so that the pipilas can deposit their eggs and brood. Other supplementary materials in the pen are chicken wire $(11 \%)$, and entwined branches for the roof which is built with fresh and dry palm branches. It is also common to observe the animals loose in the backyard adjoining the house, where they feed on herbs and insects. When afternoon arrives, the women find and herd the turkeys, hens and pigs, along with their young, back to their pen enclosures. To avoid confusion with animals regarding their ownership, a colored string is tied to one of their legs; the same is reported by Bautista (2006) for the Mixe region in Oaxaca.

The turkeys' diet is traditional: it consists of crushed maize, soaked tortilla, mostly vegetable scraps from the house, and termites. In the state of Morelos, García et al. (2012) also report maize, squash seeds, peanuts, and mango fruit. López et al. 
desperdicios de la casa, principalmente verdura y termitas. Para el estado de Morelos, García et al. (2012) reportan además de maíz, la semilla de calabaza, cacahuate y fruta de mango. López et al. (2008) mencionan que los granos de maíz son el alimento tradicional del guajolote, junto con tortilla remojada y frutos de la región. El uso de alimentos balanceados no se presenta, ya que a mención de una de las informantes son caros, además alimentando a los guajolotes con comida natural los habitantes de las comunidades el Papayo, las Salinas y Marquelia de la Costa Chica de Guerrero recurren a la comunidad de Playa Ventura para comprar a los guajolotes y gallinas, porque en su opinión, la carne es más limpia y sabrosa. Otra forma de alimentarlos es por el pastoreo de plantas silvestres e invertebrados que se localizan en los traspatios o áreas aledañas a la casa. Esto significa que es un sistema que no permite la inversión de dinero para su sostenimiento, y que la posibilidad de la venta está basada en el reconocimiento de la salud del producto al ser alimentado de manera natural.

Se reportan dos tipos de enfermedades frecuentes en la época de lluvias: la viruela (75 \%) y diarreas (25\%), López et al. (2008) también las reportan para la región del Balsas, y García et al. (2012) para Morelos. En la época de frio se reportan catarro y gripa. Es evidente la nula vacunación y desparasitación, el tratamiento de las enfermedades se realiza mediante la utilización de remedios caseros (91\%): untan tomate asado, limón o "lodo" que extraen de la laguna "cabeza de charco" en la parte afectada o cuerpo del animal para curar la viruela. Para combatir la diarrea se les da a tomar agua de coco (Cocos nucifera) o agua con cal. Solo aquellos productores $(9 \%)$ que destinan su producción exclusivamente a la venta utilizan vacunas o pagan un veterinario. La falta de aplicación de vacunas a los guajolotes por parte de las mujeres de la comunidad de Playa Ventura es similar a la reportada para Morelos (García et al., 2012), Michoacán (López et al., 2008), Oaxaca, (Bautista, 2006) y Puebla (Hernández et al., 2005), cabe señalar que algunas mujeres $(n=4)$ mencionaron colocar un pedazo de carne de víbora de cascabel en agua, misma que posteriormente dan a beber a los animales. Según mención de las personas entrevistadas esto permite que los guajolotes no se enfermen. Otras mencionaron que es mejor dejarlos andar libres porque al comer plantas silvestres los protege contra enfermedades, una informante mencionó que deja libres a sus animales en la época de lluvias para que se alimenten de renacuajos, lo cual
(2008) mention that maize grains are the traditional food for turkeys, along with soaked tortilla and regional fruit. The use of balanced meals is not present because it is expensive, according to one of the informants; also, by feeding the turkeys with natural fodder, the residents of the communities of El Papayo, Las Salinas, and Marquelia in the Costa Chica of Guerrero resort to the community of Playa Ventura to buy turkeys and hens, because in their opinion, the meat is cleaner and more flavorful. Another way of feeding the turkeys is by having them graze the wild plants and invertebrates that are found in the backyards or areas surrounding the house. This means it is a system that does not necessitate the investment of money for its maintenance, and that the possibility of sale is based on the recognition of the product's health, a result of being fed naturally.

Two types of frequent diseases are reported during the rainy season: turkey pox $(75 \%)$ and diarrhea (25 \%). López et al. (2008) also report them in the region of the Balsas, and García et al. (2012) in Morelos. During the cold season, catarrh and avian flu are reported. The complete lack of vaccination and deworming is evident. Treatment of the diseases is performed with home remedies (91\%): they slather grilled tomatoes, lime juice, or "mud" that they obtain from the Cabeza de Charco lagoon onto the affected area or entire body of the animal to cure the turkey pox. To combat diarrhea, they give the turkeys coconut water (Cocos nucifera) to drink, or water with lime (calcium hydroxide). Only those producers (9\%) who allot their production exclusively for sale utilize vaccines or pay for veterinary care. The lack of vaccine application in the turkeys by the women of the Playa Ventura community is similar to that reported in Morelos (García et al., 2012), Michoacán (López et al., 2008), Oaxaca (Bautista, 2006), and Puebla (Hernández et al., 2005). It is worth noting that some women $(n=4)$ mentioned the practice of placing a piece of rattlesnake meat in water, which is then given to the animals to drink. According to these interviewed people, this prevents the turkeys from getting sick. Others stated that it is better to allow free foraging, because eating wild plants protects them against disease; one informant mentioned allowing her animals to forage freely during the rainy season so that they can feed on tadpoles, which also allows them to prevent sickness. Lime or ashes are also used, scattered in the pens to counteract 
también permite que no se enfermen. También se utiliza cal o ceniza que se dispersa en los corrales para contrarrestar las enfermedades y contagios de otros animales. Cuando hay animales enfermos se sacan del corral y se amarran hasta que se curan. El uso de medicina herbolaria utilizada para contrarrestar las enfermedades que atacan a la ganadería de traspatio también es registrado por Jiménez et al. (2012).

Los conocimientos tradicionales respecto al uso y manejo del guajolote son transmitidos de una generación a otra, en donde las mujeres (amas de casa), juegan un papel fundamental al mantener vigente la cría de pípilas principalmente para el sustento familiar, además de ser un espacio donde se reúne la familia, platica y transmiten conocimientos. Además, las prácticas de cría del guajolote se recrean en los intercambios de experiencias y animales dentro y fuera de la comunidad.

Para las mujeres, las razones por las que se mantiene vigente la cría del guajolote y otros animales de traspatio, como las gallinas, son: aporte de carne y huevos a la alimentación familiar (89 \%), por tradición familiar $(65 \%)$, por la venta (9\%), por ser obsequios para las fiestas de la comunidad (10 \%). Similares motivos se reportan en Morelos (García et al., 2012) y en la región Mixe de Oaxaca (Bautista, 2006). Además, Rejón et al. 1996 mencionan que la ganadería de traspatio tiene como objetivo crear un fondo que permita a la familia subsistir en épocas de crisis, asegurando el mínimo básico de subsistencia (calorías) para reponer el gasto de energía empleado en el trabajo. Además, representa una fuente de ahorro y ganancia económica para situaciones de emergencia.

Algunas mujeres $(n=35)$, expresaron que anteriormente la cría de otros animales de corral como los puercos, cabras y vacas formaban parte de la ganadería de traspatio, pero debido a la falta de espacio en la casa se han ido eliminando. Otras causas son la falta de interés por las generaciones jóvenes, que mencionan que requieren muchos cuidados y que es mejor dedicarse al turismo o a la pesca. Aquino et al. (2003) reportan para el estado de Veracruz otras causas como las enfermedades o depredación, el no consumo de carne y la falta de cerco.

\section{Destino de los productos}

En la comunidad en estudio se registraron dos tipos de unidades de producción de guajolote de acuerdo al destino de la cría: diseases and contagion from other animals. When there are sick animals, they are taken out of the pen and tied separately until they are cured. The use of herbal medicine to treat diseases that attack backyard livestock is also registered by Jiménez et al. (2012).

Traditional knowledge regarding the use and management of the turkey is passed on from one generation to another, where women (housewives) take on a fundamental role in maintaining the significance of rearing pipilas, chiefly for family sustenance; the backyard is also a space where the family can gather together, converse, and pass on knowledge. Moreover, the turkey breeding practices are recreated in the exchange of experiences and animal trade inside and outside the community.

For the women, the reasons why breeding turkeys and other backyard animals, such as hens, is still current, are: they serve as a source of meat and eggs for the family diet ( $89 \%$ ), because of family tradition $(65 \%)$, for their sale $(9 \%)$, and to be presented as gifts at community festivities (10\%). Similar motives are reported in Morelos (García et al., 2012) and in the Mixe region of Oaxaca (Bautista, 2006). Also, Rejón et al. (1996) mention that backyard livestock production has the objective of creating a lifeline that allows the family to subsist in times of crisis, ensuring basic minimal sustenance (calories) to replace the energy spent in labor. Likewise, it represents a source of savings and economic income for emergency situations.

Some women $(n=35)$ expressed that formerly, the breeding of other pen animals like pigs, goats, and cows was part of their backyard livestock production, but due to the lack of space at home they have been gradually eliminated. Other causes are the lack of interest displayed by the younger generations, who mention that livestock requires too much care and it is better to devote their time to tourism or fishing. Aquino et al. (2003) report other causes for the state of Veracruz, such as diseases or depredation, non-meat consumption, and the lack of enclosures.

\section{Product destination}

In the community of study, two types of turkey production units were registered according to their final destination: 
1. Unidades de autoconsumo (91\%), que son aquellos que destinan sus guajolotes para el sustento de la familia, y que ven en los guajolotes una caja de ahorro, ya que sólo se venden cuando se tiene alguna necesidad o como ellos llaman, "urgencia".

2. Unidades comerciales (9\%), que destinan su producción exclusivamente para la venta.

Por tanto, se resalta el destino de la producción para el autoabasto familiar. Comparativamente, para la Costa de Oaxaca $68 \%$ de los productores destinan sus aves al autoconsumo, $29 \%$ a la venta, $1.5 \%$ los dan como obsequios y un porcentaje igual lo destinan a apuestas (Camacho et al., 2006).

El sistema de aves de traspatio se encuentra ampliamente distribuido en América Latina, en Asia y África, que abastecen necesidades sociales, religiosas; y por el aporte de carne y huevos (Sonaiya et al., 2002). En México, para las poblaciones campesinas la crianza de guajolote nativo M. gallopavo Linn. en el traspatio es una actividad tradicional y constituye un importante aporte alimentario e ingreso económico (Medrano, 2000). Los usos registrados en este trabajo son: alimento (80\%), obsequios y regalos (15\%), medicinal (5\%), y $100 \%$ mencionó el uso del excremento como abono.

El uso alimentario se refiere al consumo de huevos y carne, se prepara en mole rojo o mole de pipián, asado con chile ajo, en caldo o frito. Lafòn (1997), Losada et al. (2006), Camacho et al. (2012) y García et al. (2012) mencionan la importancia del uso alimentario y su variedad de formas de uso que las mujeres otorgan al guajolote nativo. Llamas (2005), señala la importancia del guajolote en la alimentación familiar porque aporta más proteínas que el cerdo y el pollo, menos grasas que el pollo, res, cerdo y codorniz y más calorías que el pollo, res, conejo y codorniz. Además es rico en vitaminas B1, B3, B5, B6 y B12, biotina, ácido fólico, fosforo, hierro y zinc. Lo anterior, refuerza lo planteado por Guèye (2003) y García et al. (2012) respecto a que la ganadería de traspatio en comunidades rurales, contribuye a mitigar la falta de recursos económicos mediante la venta de los guajolotes y sus productos, además se asegura la alimentación de las familias campesinas.

El uso como obsequio, presenta tres destinos:
1. Auto-consumption units (91\%), which are those that use their turkeys for family sustenance, and which view the turkeys as a savings account, since they are only sold when there is a need, or as they call it, "urgency".

2. Commercial units (9\%), which destine their production exclusively for sale.

Thus, production destined for family self-sufficiency stands out. Comparatively, in the coast of Oaxaca, $68 \%$ of the producers use their birds for personal consumption, $29 \%$ for sale, $1.5 \%$ as gifts, and an equal amount for betting (Camach et al., 2006).

The backyard bird system is distributed widely throughout Latin America, Asia, and Africa, satisfying social and religious needs, in addition to contributing meat and eggs (Sonaiya et al., 2002). In México, the breeding of the native turkey (M. gallopavo Linn.) in the backyard is, for peasant populations, a traditional activity that constitutes an important contribution to the diet and economic income (Medrano, 2000). The uses registered for this activity are: food (80\%), gifts (15\%), medicinal (5\%), and $100 \%$ mentioned using the excrement as manure.

The dietary use refers to the consumption of eggs and meat, which is prepared in mole rojo or mole de pipián, roasted with pepper and garlic, in soup or fried. Lafòn (1997), Losada et al. (2006), Camacho et al. (2012) and García et al. (2012) mention the importance of the use as food and the variety of forms of use that women give native turkey. Llamas (2005) points out the importance of turkey in the family diet because it contributes more proteins than pork and chicken, less fat than chicken, beef, pork and quail. In addition, it is rich in vitamins B1, B3, B5, B6 and B12, biotin, folic acid, phosphorus, iron and zinc. This supports what was stated by Guèye (2003) and García et al. (2012), with regard to backyard livestock production in rural communities contributing to mitigate the lack of economic resources through the sale of turkeys and their byproducts, and also ensuring the diet of the peasant families.

The use as a gift presents three destinations:

1. During religious festivities, it is customary to gift backyard animals,

2. When there is a visit to extended family (compadres), turkey mole is presented, and 
1. En fiestas religiosas, se acostumbra a regalar animales de traspatio,

2. Cuando se visita a los compadres se les lleva mole de guajolote $y$,

3. En los cumpleaños, bodas o bautizos se preparan diferentes guisos.

Para uso medicinal, se utilizan los huevos o los animales vivos para curar algunos síndromes de filiación cultural como el "aire", el "daño" o "mal de ojo" principalmente a los niños. Consiste en tomar un huevo o el animal y frotar sobre el niño con el padecimiento, pidiendo a Dios su cura. Camacho et al. (2012) reportan el uso de la grasa y plumas de guajolote en la medicina tradicional en la cultura de los pueblos Ayuuk, Chinantecos y zapotecos de la Sierra Juárez de Oaxaca. En todos los traspatios es común el uso del excremento del guajolote y gallinas como abono para los cultivos o plantas comestibles o medicinales.

Otros usos que se han registrado en México es la utilización de sus plumas para hacer mantas ceremoniales, adornos para la cabeza, para el balance de flechas; además del espolón para las puntas de flechas. En la cerámica es frecuentemente el uso de dibujos de esta ave (Llamas, 2005).

Son tres las mujeres que crían guajolotes exclusivamente para la venta, quienes se encargan de comercializarlas en los restaurantes locales o en los mercados de Marquelia y Copala en la Costa Chica de Guerrero.

Los productos que son destinados para la venta son el huevo, con un costo por unidad de $\$ 2.00$ a 5.00 , los animales juveniles se venden en $\$ 30$ a $\$ 60$, el animal adulto vivo se vende en $\$ 150$ en temporada baja y de $\$ 250$ a $\$ 350$ dependiendo de la época y ocasión, como en bautizos, bodas, y en diciembre que es cuando arriban a la comunidad turistas para festejar la navidad. La contribución de la ganadería familiar al ingreso, es a partir de la función de ahorro que tiene la crianza de guajolotes nativos y poder solventar algunas necesidades básicas de la familia, al vender o intercambiar. Mujeres provenientes de otros pueblos arriban a la comunidad, de las Salinas se intercambia sal de mar, del Papayo maíz o frijol, sandías, papayas y de Marquelia llevan pescado para poder intercambiarlos por animales del traspatio. Las pípilas se ponen a la venta después de por lo menos tres periodos de reproducción ("puestas"), es decir entre 1 a 3 años de
3. For birthdays, weddings, or baptisms, different dishes are prepared.

In medicinal use, eggs or live animals are used to cure certain syndromes of cultural affiliation, such as "air", "damage", or "evil eye", mainly in children. This consists in taking an egg or the animal and rubbing it on the child with the ailment, asking God for a cure. Camacho et al. (2012) report the use of turkey fat and feathers in the traditional medicine of the cultures of the Ayuuk, Chinantecos and Zapoteco peoples, in the Sierra Juárez mountains in Oaxaca. In all backyards, it is common to use hen and turkey excrement as fertilizer for crops or edible and medicinal plants.

Other uses that have been recorded in México include the utilization of feathers to make ceremonial blankets, head ornaments, and arrow fletching; likewise, the turkey's spur is used for arrowheads. In ceramics, images of this bird are commonly depicted (Llamas, 2005).

There were three women who breed turkeys exclusively for sale, who were in charge of commercializing them in local restaurants or in the markets of Marquelia and Copala, along the Costa Chica coast of Guerrero.

The products that are destined for sale are eggs, with a price per unit of $\$ 2.00$ to $\$ 5.00$ pesos, juvenile animals with a price of $\$ 30$ to $\$ 60$ pesos, live adult animals that sell for $\$ 150$ pesos during low season and $\$ 250$ to $\$ 350$ pesos depending on the season and occasion; for example, for baptisms, weddings, and the month of December when tourists arrive in the community to celebrate Christmas. The contribution that family livestock production makes to the income is based on the role in savings that native turkey breeding provides, also facilitating certain basic necessities of the family from selling or exchanging. Women from other towns visit the community: from Las Salinas they trade sea salt, from Papayo they trade maize, beans, watermelons, and papayas, and from Marquelia they trade fish for backyard animals. The pipilas are put on sale after at least three periods of reproduction (puestas, egg-laying), that is to say between 1 and 3 years of permanence in the family unit, in order to take advantage of their reproductive capacity and to maintain the system current. 
permanencia en la unidad familiar, para aprovechar su capacidad reproductiva y mantener vigente el sistema.

\section{Conclusiones}

La cría de guajolote como componente de los traspatios y estrategia familiar en Playa Ventura es una actividad productiva tradicional permanente y persistente, la cual proporciona alimentos cotidianos a la familia, proteína de origen animal mediante el consumo de huevo y carne y, en menor medida, se obtienen ingresos económicos por las ventas.

La cría de pípilos, bajo el sistema en que se lleva a cabo se basa en el uso de materiales locales para la construcción de instalaciones y se busca minimizar la alimentación adicional. El trabajo se asocia a las actividades del traspatio en general y se distribuye entre los miembros de la unidad familiar, organizado por las mujeres.

Las prácticas de cría están inmersas en dinámicas de relaciones con otras unidades familiares y hacia el exterior de la comunidad, lo que permite mantener la persistencia de los pípilos y el sistema vigente; así los conocimientos para el manejo de alimentación, enfermedades y reproducción traspasan el límite del traspatio individual a través de intercambios, préstamos, pláticas y ventas; lo cual permite enfrentar las dificultades de un sistema vulnerable, que de manera individual no podría sostenerse en todas las unidades.

La cría de guajolotes puede subsistir porque se articula a las actividades y aportes del traspatio en general, con la cría de otros animales y el cultivo de otras plantas. De igual modo el trabajo y organización forma parte de un sistema diverso, el cual, a su vez se integra a una estrategia en la que cada actividad aporta recursos para la subsistencia de las familias campesinas de la comunidad.

Las mujeres, con su trabajo, llevan a cabo la crianza de guajolotes y otros animales, así como la organización del traspatio. Esta actividad se transmite a través de la misma práctica a las siguientes generaciones y se va adecuando a los cambios que la comunidad vive.

\section{Agradecimientos}

Al Consejo Nacional de Ciencia y Tecnología por la beca otorgada para realizar los estudios de Doctorado del primer autor. A las mujeres de la comunidad de Playa Ventura, quienes aportaron su

\section{Conclusions}

Turkey breeding, as a component of backyards and family strategy in Playa Ventura, is a traditional productive activity that is permanent and persistent, which provides everyday food for the family including animal protein by means of the consumption of eggs and meat, and, to a lesser degree, economic income from sales.

Raising pipilos, under the system that is carried out, is based on the use of local materials for the construction of facilities and for minimizing additional feeding. The task is associated to backyard activities in general and is distributed among family unit members, organized by the women.

Breeding practices are immersed in dynamics involving relations with other family units and outside the community, which allows maintaining the persistence of pipilos and the current system; in this way, knowledge regarding feeding, diseases, and reproduction transcend the limits of the individual backyard through exchanges, loans, conversations, and sales. This allows facing the difficulties of a vulnerable system that could not be sustained individually across all units.

The breeding of turkeys continues to subsist because it articulates the activities and contributions of the backyard in general, with the rearing of other animals and the cultivation of plants. Likewise, work and organization are part of a diverse system that, in turn, is integrated in a strategy in which each activity contributes resources for the subsistence of the community's peasant families.

The women, through their work, carry out the breeding of turkeys and other animals, as well as the organization of the backyard. This activity is passed on through the practice itself to the next generations, and continues to adapt to the changes that the community experiences.

\section{ACKNOWLedgements}

To the National Council of Science and Technology (Consejo Nacional de Ciencia y Tecnología) for the scholarship granted to carry out $\mathrm{PhD}$ studies by the first author. To the women of the community of Playa Ventura, who contributed their knowledge and valuable time, especially to Reina Pérez Ventura 
conocimiento y su valioso tiempo, en especial a las señoras Reina Pérez Ventura y Luz Argüello González, quienes fueron mi guía en la comunidad.

\section{Literatura Citada}

Allende, N. R., Jerez, S. M. P., Vázquez, D. M. A., y Villegas, A. Y. 2012. Estudio Etno-ornitológico Auuk en Zompantle, Asunción Cacalotpec, Oaxaca. In: Vázquez, D. M. A. y Lope, A.D. G. (eds). Las aves de traspatio. Aves y Huertos de México. Instituto Tecnológico del Valle de Oaxaca. pp:48-49.

Aquino, R., Arroyo, A. L., Torres, H. G., Riestra, D. D., Gallardo, L. F., y López, Y. B. A. 2003. El guajolote criollo ( $\mathrm{Me}-$ leagris gallopavo L) y la ganadería familiar en la zona centro del Estado de Veracruz. Técnica Pecuaria en México Vol. 41 Núm. 2. pp:165-173.

Barrera, A. 1983. Perspectivas para el Quehacer Etnobotánico en México. In: Barrera, A (ed). La Etnobotánica: Tres Puntos de Vista y una Perspectiva. Instituto Nacional de Investigaciones sobre Recursos Bióticos. Xalapa, México. pp: 25-28.

Bautista, J. M. 2006. Diseño de una estrategia de transferencia de tecnología en la ganadería campesina de la región Mixe (Ayuuk) en Oaxaca, México. Raximhai Vol. 2. Núm. 2. pp: 419-433.

Bellamy, R. 1996. Ethnobiology in Tropical Forests. Edit. Expedition Advisory Centre. London. pp: 18-35.

BSTID (Board of Science and Technology for International Development). 1991. Microlivestock: little-known small animals with promising economic future. National Academies Press. pp:157-166.

Burcher, de Uribe P. 1996. Origen de los animales domésticos. Universidad de Antioquia. Colombia. 188 p.

Camacho, E. M. A., T. I. Lira, C. L. Ramírez, P. R. López, y G. J. L. Arcos. 2006. La avicultura de traspatio en la costa de Oaxaca México. Ciencia y Mar Vol. X. Núm 28. pp: 3-11.

Camacho, E. M. A., Ramírez, C. L., T. I. Lita, y S. V. Hernández. 2008. Phenotypic characterization of the guajolote (Meleagris gallopavo gallopavo) in México. Animal Genetic Resources Information. Vol. 43. pp: 59-66.

Camacho, E. M. A., J. C. Kollas, S. M. P. Jerez, L. J. Arroyo, A. N. Y. Serrano, y B. E. I. Sánchez. 2012. Los guajolotes (Meleagris gallopavo L.) en la cultura de los pueblos ayuuk, chinanteco y zapoteco de la Sierra Juárez de Oaxaca. In: Vázquez, D. M. A. y Lope, A.D.G. (eds). Aves y Huertos de México. Instituto Tecnológico del Valle de Oaxaca. pp: 50-51.

Castellanos, E. I. 2004. Punto de acuerdo en relación a la importación de carne de pavo a México. Gaceta del Senado de la República No. 85. México.

Costa-Neto, E. 2000. Conhecimiento e uso tradicional de recursos faunísticos por una comunidade Afro-Brasileira. Resultados preliminares. Interciencia. Vol. 25. Núm. 9. pp: 423-431.

Cragnolino, E. 2002. La unidad doméstica en una investigación de antropología educativa. Congreso argentino de antropología social. Universidad Nacional de Cordoba. http://www. naya.org.ar/congresos/contenido/laplata/LP5/16.htm

Delgado, M. J. 2008. Persistencia, conocimiento local y estrategias de vida en sociedades campesinas. Revista de Estudios Sociales. No.29. Bogota. pp: 122-133. and Luz Argüello González, who were my guide in the community.

- End of the English version -

Díaz del Castillo, B. 2009. Historia Verdadera de la Conquista de la Nueva España. Ed. Porrúa, México. 112 p.

Estrada, L. E., E. Bello, y L. Serralta. 1998. Dimensiones de la etnobotánica: el solar maya como espacio social. In: Cuevas S. J. A. et al., 1998. Lecturas en etnobotánica, publicaciones del programa nacional de etnobotánica.1. Universidad Autónoma Chapingo. Estado de México. pp: 457-474.

FAO (Food and Agriculture Organization). 2001. Descriptores de especies avícolas. In: Banco de datos de recursos genéticos. Organización de las Naciones Unidas para la Agricultura y la Alimentación. Roma.

FAO (Food and Agriculture Organization). 2002. Avicultura familiar. www.fao.org (Consultado el 28 de Septiembre del 2010).

García, F. A., B. H. Colin, y R. Monroy. 2012. Uso y manejo del guajolote Meleagris gallopavo en la comunidad de Xoxocotla, Morelos. Mesoamericana. Vol.16. Núm. 1. pp: 9- 17.

García, F. A. 2013. Conocimiento, uso y manejo de los recursos naturales en la comunidad Juan Nepomuceno Álvarez, municipio de Copala, Guerrero, México. Tesis de Doctorado en Ciencias Agropecuarias y Desarrollo Rural. Facultad de Ciencias Agropecuarias. Universidad Autónoma del Estado de Morelos.

Gutiérrez, R. E.J., Aranda, C. F. J., Rodríguez V. R. I. Bolio G. M. E. Ramírez, G. S., y Estrella, T. J. 2012. El sub-sistema de producción animal de traspatio en Yucatán, México. Bioagrociencias. Vol. 5. Núm. 1. pp: 20-28.

Guèye, E. F. 2003. Information dissemination for family poultry research and development. Livestock Research for Rural Development. Vol.15. Núm 2. pp: 1-10.

Hernández, J. S., M. R. Oviedo, A. S. Martínez, L. L. Carreon, M. R. Resendiz, B. J. Romero, M. J. Ríos, G. J. Zamitiz, y S. Vargas. 2005 Situación del guajolote común en la comunidad de Santa Ursula (Puebla, México). In: Memorias del VI Simposio Iberoamericano sobre conservación y utilización de recursos zoogenéticos. San Cristóbal de las Casas, Chiapas, México. pp: 277-281.

Hernández, P. J. O., y P. P. X. Jaimes. 2003. La participación de las mujeres en el manejo integral del traspatio. Gobierno del estado de Chiapas. Instituto de la Mujer, Chiapas. 50 p.

INEGI (Instituto Nacional de Estadística Geografía e Informática). 2010. Anuario estadístico del estado de Guerrero. México.

INEGI (Instituto Nacional de Estadística Geografía e Informática). 2009. Prontuario de información geográfica municipal en los Estado Unidos Mexicanos. Copala, Guerrero.

Jerez, S. M. 1994. La gallina criolla en los valles centrales de Oaxaca. In: Jerez, S. M. P. J., Herrera, H., y Vázquez, M. A. La gallina criolla en los valles centrales de Oaxaca. Reporte de investigación No.1. Instituto Tecnológico Agropecuario de Oaxaca-Centro de Investigación y Graduados Agropecuarios. Oaxaca.

Jiménez, D. J. E., D. M. A. Vázquez, P. E. Naranjo y S. M. P. Jerez. 2012. Etno Ornitología maya de Lacanjá-Chansayab, 
Chiapas. In: Vázquez, D. M. A. y Lope, A.D. G. (eds). Aves y Huertos de México. Instituto Tecnológico del Valle de Oaxaca. pp. 28-29.

Juan, P. J. I., y U. D. Madrigal. 2005. Huertos, diversidad y alimentación en una zona de transición ecológica del estado de México. Ciencia Ergo Sum. Vol.12. Núm. 1. 99: 54-63.

Lafòn, A. 1997. Distribution, habitat use and ecology of Gould's Turkey in Chihuahua, Mexico. Doctor of philosophy thesis. Las cruces New México. State University.

Lanza, V. C., y M. J. Rojas. 2010. Estrategias de reproducción de las unidades domésticas campesinas de Jucuapa Centro, Nicaragua. Agricultura, Sociedad y Desarrollo. Vol. 7. Núm. 2. pp: 169-187.

Lerner, M. T., M. R. Mariaca, I. B. Salvatierra, J. A. González, y K. E. Wall. 2009. Aporte de alimentos del huerto familiar a la economía campesina Ch'ol, Suclumpò, Chiapas, México. Etnobiología Vol. 7. pp: 30-44.

López, Z. R., C. H. Cano, R. T. C. Monterrubio, N. O. Chassin, R. U. Aguilera, y P. M. G. Zavala. 2008. Características morfológicas y de producción de guajolotes (Meleagris gallopavo) criados en sistema de traspatio en el Estado de Michoacán, México. Livestock Research for Rural Development. Vol. 20. No. 5. http://www.lrrd.org/lrrd20/5/lope20068.htm

Lok, R. 1998. Introducción a los huertos caseros tradicionales tropicales. Módulo de enseñanza agroforestal. No.3. Centro agronómico tropical de investigación y enseñanza-GTZ. 157 p.

Llamas, J. M. 2005. El guajolote. Asociación Nacional de Tiendas de Autoservicio y Departamentales A. C. (ANTAD). 24 p.

Losada, H., Rivera, J., Cortes, J., Castillo, A., González, R. O., y Herrera, J. 2006. Un análisis de sistemas de producción de guajolotes (Meleagris gallipavo) en el espacio suburbano de la delegación Xochimilco al sur de la Ciudad de México. Livestock Research for Rural Development. Vol. 18. http:// www.lrrd.org/lrrd18/4/losa18052.htm

Martin, Gary. 1997. Ethnobotany people and plants conservation. Chapman and Hall, London. 267 p.

Martínez, R. y S. Domínguez. 1992. La planificación regional y el desarrollo. Instituto de Investigaciones y Estudios Superiores Económicos y Sociales de la Universidad Veracruzana. México.

Medrano, J. A. 2000. Recursos animales locales del centro de México. Arch. Zootec. Vol. 49. pp: 385-390.

Rejón, M. J., A. F. Dajer, y N. Honhold. 1996. Diagnóstico comparativo de la ganadería de traspatio en las comunidades Texàn y Tzacala de la zona henequera del estado de Yucatán. Veterinaria México. Vol. 27. Núm. 1. pp: 49-55.

Rodríguez, G. G. 2006. Análisis del sistema de producción agropecuario en colonias indígenas de San Cristóbal. Tesis. Maestría en Agroecología Tropical. FCA-UNACH. Villaflores, Chiapas, México. 135 p.
Rodríguez, G. G., M. L. Zaragoza, y G. R. Perezgrovas. 2010. Los valores disimulados de la producción animal de traspatio. In: Memorias del XI Simposio iberoamericano sobre utilización y conservación de recursos zoogenéticos locales. João Pessoa-Paraiba, Brasil. pp. 36-39.

Rodríguez, G. G., N. Sanabria, D. C. Ramírez, M. L. Zaragoza, y G. R. Perezgrovas. 2012. La gallina de rancho, elemento cotidiano del sistema de vida en la familia rural en la Frailesca Chiapaneca. In: Vázquez, D. M. A. y Lope, A.D. G. (eds). Aves y Huertos de México. Instituto Tecnológico del Valle de Oaxaca. pp: 36-37.

Rodríguez, J. C., C. E. Allaway, G. J. Wassink, J. C. Segura, y T. Rivera. 1996. Estudio de la avicultura de traspatio en el municipio de Dzununcàn, Yucatán. Veterinaria México. Vol. 27. Núm. 3. pp: 215-219.

Román, P. H. 1989. Fauna doméstica. In: Mosqueda V. R., Ruiz R. O. y Ávila R. C. (comps). Retrospectiva y perspectivas de la investigación en el uso de los recursos naturales del trópico mexicano en Tepetates Veracruz. pp: 59-82.

SAGARPA (Secretaria de Agricultura, Ganadería, Desarrollo rural, Pesca y Alimentación). 2002. Anuario estadístico de la producción pecuaria en los Estados Unidos Mexicanos 2001. Servicio de información y estadística agroalimentaria y pesquera. 33, 67, 92.

Sántiz, R. G., G. R. Perezgrovas, G. G. Rodríguez, y M. L. Zaragoza. 2012. Importancia socioeconómica y cultural de las gallinas locales en una comunidad Tsotsil de Chiapas. In: Vázquez, D. M. A. y Lope, A. D. G. (eds). Aves y Huertos de México. Instituto Tecnológico del Valle de Oaxaca. pp. 34-35.

Soler, F. D. M. 2010. Importancia de los sistemas avícolas campesinos (pollo de engorde y gallina ponedora) dentro de la unidad productiva y su aporte a la seguridad alimentaria: Estudio de caso Vereda La Pradera, municipio de Duitama, Boyaca. Tesis de Maestría en Desarrollo Rural. Facultad de Estudios Ambientales y Rurales. Pontifica Universidad Javeriana. Colombia. 129 p.

Sonaiya, E. B., R. D. S. Branckaert, y E. F. Gueye. 2002. Research and development options for family poultry. http:// www.fao.org/ag/againfo/subjects/en/infpd/econf_scope. html

Steinberg, M. K. 1998. Neotropical kitchen gardens as a potential research landscape for conservation biologist. Conservation Biology. Vol. 12. Núm 5. pp: 1150-1153.

Sturtevant, W. C. 1964. Studies in ethnoscience. Am. Anthropol. Vol. 66. Núm. 30. pp: 99-131.

Valadez, R. A. 2003. La domesticación animal. Plaza y Valdez. México D. F.

Vieyra, J., A. Castillo, H. Losada, J. Cortes, G. Alono, T. Ruiz, P. Hernández, A. Zamora, y A. Acevedo. 2004. La participación de la mujer en la producción de traspatio y sus beneficios tangibles e intangibles. Cuadernos de Desarrollo Rural. Vol. 53. pp: 9-23. 